\title{
Nitrate Removal from Groundwater by Nanoscale Zero-Valent Iron (NZVI) Coupling Autohydrogenotrophic Denitrification
}

\author{
Wang Hongyu*, Zhang Shilu, Chen Dan, He Qiulai \\ School of Civil Engineering \\ Wuhan University \\ Wuhan, China \\ e-mail: whydream2000@163.com \\ * Corresponding Author
}

\begin{abstract}
In this work, the denitrification performance of a bio-reactor based on nanoscale zero-valent iron (NZVI) coupling autohydrogenotrophic denitrification was investigated. A series of bio-reactors were configured by inoculating and acclimating pure culture capable capable of denitrification. Effects of various parameters including nitrate (NO3-_N) loading, NZVI to nitrogen ratio $(\mathrm{Fe} / \mathrm{N}), \mathrm{pH}$ and atmosphere on denitrification were evaluated by batch tests. The results showed that the optimum Fe/N and NO3-$\mathrm{N}$ loading were 2.8 and $105 \mathrm{mg} / \mathrm{L}$, respectively. Dentrification process remained unaffected by $\mathrm{pH}$ ranging from 6.0 to 9.0, while sharp accumulation of nitrite (NO2-_N) occurred at pH 9.0. Complete NO3-_N removal was obtained by providing both nitrogen (N2) and hydrogen gas (H2). In general, excellent nitrogen removal efficiency was always achieved in the chemical-biological coupling system, indicating that the system had strong stability and adaptability for practical application, which offered both theoretic and technical supports to a new efficient and costeffective method to eliminate NO3-_N from water.
\end{abstract}

Keywords-Nitrate removal; NZVI; chemical denitrification; autohydrogenotrophic denitrification; coupling system.

\section{INTRODUCTION}

With the rapid development of industrialization and overuse of synthetic fertilizers, nitrate (NO3-_N) has contaminated groundwater in many countries over years [1]. Nowadays, scientific approaches for removing NO3_ $\mathrm{N}$ have gained great attention due to the fact that high level of NO3-_N may cause diseases such as methemoglobinemia and cancer [2]. Many countries thus promulgate specific regulation to set the upper limit of NO3-_N in groundwater. The maximum value of NO3-_N nitrogen in groundwater proposed by China is $10 \mathrm{mg} / \mathrm{L}$ [3], which is in accord with World Health Organization (WHO) standard value [4].

Currently, traditional technologies for eliminating NO3-_N from groundwater include abiotic and biological methods. Abiotic treatments include reverse osmosis, electrodialysis, ion exchange, distillation and catalytic reduction etc [5]. However, there are still some feedbacks of physicochemical methods, such as the high operating cost [6;7], low selectivity, and the generation of byproduct brine [4]. Biological denitrification has been considered one of the most common and effective approaches [8]. Although being environmental-friendly and economical, it has some apparent disadvantages: residue of bacteria and organic matter, high yield of surplus sludge, and managerial difficulties.

Traditional technologies can no longer match the requirements of wastewater discharge for the increasing sewage discharge and high cost. It is essential to develop an alternative approach. In recent years, with the development of nanotechnology, nanoscale zero-valent iron (NZVI) has raised concern due to its huge surface area, excellent surface adsorption and chemical reaction activity $[9 ; 10]$. Previous studies on NZVI denitrification were pretty rare. The high cost and requirement for $\mathrm{pH}$ also limit its further application. NZVI-based microbial hydrogen-utilizing denitrification for NO3-_N removal has been proposed and verified as a promising approach [11;12]. Therefore, a couple system by combining chemical denitrification with biological denitrification was constructed for potential NO3__N removal.

In this work, a bio-reactor by coupling chemical and biological denitrification was developed. The purpose of this work was to investigate the effects of various factors including NO3-_N loading, $\mathrm{pH}$, iron to nitrogen ratio $(\mathrm{Fe} / \mathrm{N})$ and atmosphere on denitrification performance, aiming to add some novel insight into NO3-_N removal by chemical-biological denitrification.

\section{MATERIALS AND METHODS}

\section{A. Experiment set-up}

Four airtight flask with a working volume of $250 \mathrm{~mL}$ were used for batch tests in present study. Prior to batch experiments, domesticated anaerobic sludge $100 \mathrm{~mL}$ (mixed liquor suspended solids (MLSS) $77.9 \mathrm{~g} / \mathrm{L}$, mixed liquor volatile suspended solids (MLVSS) $35.1 \mathrm{~g} / \mathrm{L}$ ), fresh NZVI $(10 \mathrm{ml})$ and bacterial culture media were inoculated into each flask. Continuous H2 (0.05 MPa) was introduced to the flasks to keep out oxygen. All flasks were placed into an Oven Controlled Crystal Oscillator.

\section{B. Synthetic wastewater}

The compositions of synthetic wastewater contained (per liter): NaNO3 25-150 mg, NaHCO3 $750 \mathrm{mg}$, KH2PO4 $97.5 \mathrm{mg}, \mathrm{ZnCl} 20.68 \mathrm{mg}$, CoCl2.6H2O $0.19 \mathrm{mg}$, $\mathrm{MnSO} 4 \cdot 7 \mathrm{H} 2 \mathrm{O} \quad 0.12 \mathrm{mg}, \quad \mathrm{NiCl} 2 \cdot 6 \mathrm{H} 2 \mathrm{O} \quad 0.27 \quad \mathrm{mg}$, $\mathrm{Na} 2 \mathrm{MoO} 4 \cdot 2 \mathrm{H} 2 \mathrm{O} \quad 0.36 \mathrm{mg}, \quad \mathrm{CuCl} 2 \cdot 2 \mathrm{H} 2 \mathrm{O} \quad 0.32 \mathrm{mg}$, 
$\mathrm{MgCl} 26 \mathrm{H} 2 \mathrm{O} 0.28 \mathrm{mg}$, and $\mathrm{H} 3 \mathrm{BO} 30.35 \mathrm{mg}$. $\mathrm{NaHCO} 3$ was used as the only inorganic carbon source.

\section{Domestication of denitrifying bacteria}

Denitrifying bacteria was collected from the anaerobic tank of Erlangmiao Municipal Wastewater Treatment Plant (WWTP) in Wuhan, China. The collected sludge was cultured for 30 days. About $2 \mathrm{~L}$ of anaerobic sludge (mixed liquor supernatant) was added into a bottle with nutritive material at $25^{\circ} \mathrm{C}$. The compositions of the nutritive solution were $(\mathrm{mg} / \mathrm{L})$ : $\mathrm{NaNO} 342.5, \mathrm{NaHCO} 3$ (inorganic carbon source) 750, KH2PO4 97.5 and some trace element solution. Fresh nutritive solution was cycled every 7 days. Meanwhile, sufficient H2 was supplied over process. The domestication of bacteria was accomplished when the NO3-_N degradation rate was jarless. The MLSS and MLVSS were 77.9 and $35.1 \mathrm{mg} / \mathrm{L}$, respectively.

\section{Analytical methods}

NO3--N, NO2--N, ammonia (NH4+-N), total nitrogen $(\mathrm{TN})$, ferrous ion $(\mathrm{Fe} 2+)$, iron (Fe), MLSS, and MLVSS were measured according to the standard methods [12], the $\mathrm{pH}$ was measured by $\mathrm{pH}$ meter, dissolved oxygen (DO) was measured by YSI550A DO meter and temperature was measured by thermometer.

\section{RESULT AND DISCUSSION}

\section{A. Effect of $\mathrm{Fe} / \mathrm{N}$}

Effect of $\mathrm{Fe} / \mathrm{N}$ on denitrification was shown in Figs. 1 and 2. A volume of $5 \mathrm{ml} 、 10 \mathrm{ml} 、 20 \mathrm{ml}$ and $30 \mathrm{ml}$ of NZVI solution was injected to the bioreactor to keep a Fe/N ratio of 1.4 to 8.4. The concentration of NO3--N and NH4+-N via operation time were monitored.

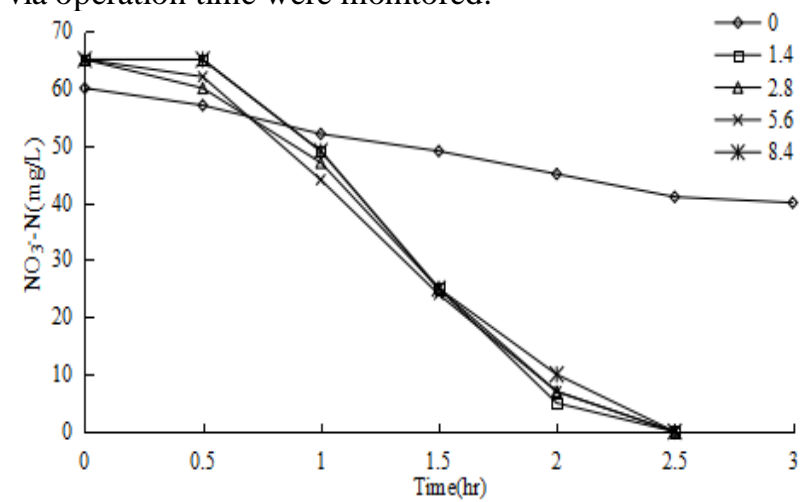

Figure 1. $\mathrm{NO}_{3}^{-}-\mathrm{N}$ removal at different $\mathrm{Fe} / \mathrm{N}\left(\mathrm{pH} 7.0, \mathrm{NO}_{3}^{-}-\mathrm{N}\right.$ loading $65 \mathrm{mg} / \mathrm{L}, \mathrm{H}_{2}$ pressure $0.05 \mathrm{MPa}$, temperature $30^{\circ} \mathrm{C}$ )

As shown in Fig. 1, Fe/N had little effect on NO3-_N removal since NO3-_N was completely removed within $2.5 \mathrm{~h}$ with $\mathrm{Fe} / \mathrm{N}$ of 1.4-8.4. Introduction of NZVI greatly enhanced the reduction rate as the average NO3-_N degradation rate for bioreactor with or without NZVI were 26 and $6.7 \mathrm{mg}$ NO3__N/L/h. It's apparently that introduction of NZVI can significantly improve the reactivity of the system, due to the high surface adsorption and chemical reaction activity of NZVI [9].

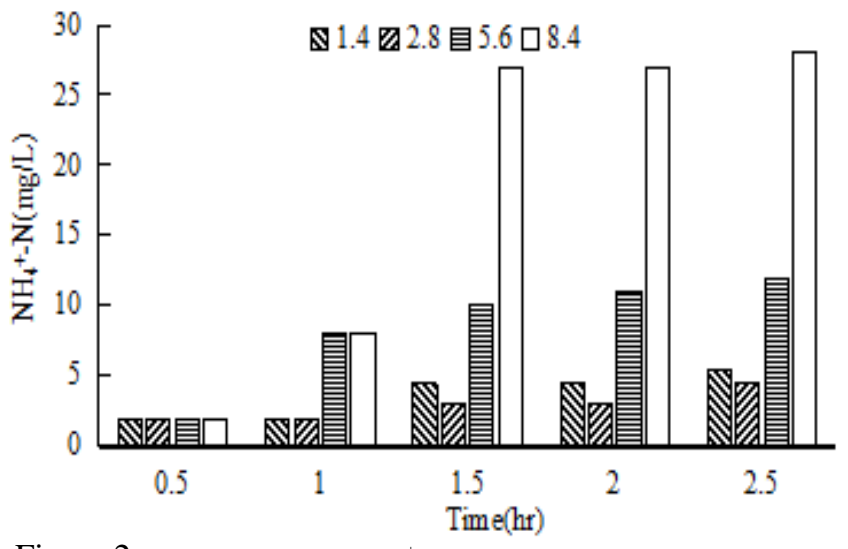

Figure 2. Effect of $\mathrm{Fe} / \mathrm{N}$ on $\mathrm{NH}_{4}{ }^{+}-\mathrm{N}\left(\mathrm{pH} 7.0, \mathrm{NO}_{3}{ }^{-} \mathrm{N}\right.$ loading $65 \mathrm{mg}$ $/ \mathrm{L}, \mathrm{H}_{2}$ pressure $0.05 \mathrm{MPa}$, temperature $30^{\circ} \mathrm{C}$ )

However, the introduction of NZVI would increase NH4+-N concentration (Fig. 2). This was because NZVI had strong reduction and excellent surface adsorption, which was active to reduce $\mathrm{NO} 3-[\mathrm{N}$ with $\mathrm{NH} 4+-\mathrm{N}$ as the main product [13]. In addition, it may also adsorb reactant or the intermediate section. Therefore, considering the denitrification rate and denitrification product, the optimum $\mathrm{Fe} / \mathrm{N}$ was 2.8 .

\section{B. Effect of $p H$}

Effect of $\mathrm{pH}$ on denitrification was present in Figs. 3 and 4. For NZVI, acidic conditions were conducive to NO3-_N removal [14], while for autotrophic denitrifying microbes, neutral or slightly alkaline environment were more advantageous [15].

It could be seen from Fig. 3 that there was no distinct discrepancy at different initial $\mathrm{pH}$ from 6.0 to 9.0 , for $100 \%$ of influent NO3-_N was eliminated within $2.5 \mathrm{~h}$. According to Xia et al [7]. the optimum $\mathrm{pH}$ for autotrophic denitrification was 7.2-8.2, with the maximum efficiency at $\mathrm{pH} 7.7$, since the over-high $\mathrm{pH}$ would affect the enzyme activity of denitrifying bacteria and lead to the deposit of iron oxides and hydroxides on the surface of NZVI thus preventing the reaction [9]. Rezania et al.[16;17] reported that when $\mathrm{pH}>8.6$, denitrification was unable to continue. In this experiment, coupling system could still remove NO3-_N completely even when $\mathrm{PH}$ at 9. This may because the domesticated activated sludge had a strong adaptive ability to alkaline environments, and NZVI improved system's activity.

NO2-_N accumulation over $\mathrm{pH}$ was present in Fig. 4. No obvious accumulation was found under $\mathrm{pH}$ 6.0-8.0. However, a maximal of $1.9 \mathrm{mg} / \mathrm{L}$ of $\mathrm{NO} 2-\_\mathrm{N}$ was detected at $\mathrm{pH}$ of 9.0. Moreover, the concentration of NH4+-N (data not shown) fluctuated slightly (below 1.0 $\mathrm{mg}$ ). This differed from the previous researches, which might because biological denitrification by autohydrogenotrophic denitrifiers dominated in coupling system, while NZVI contributed less. NH4+-N generation mainly depended on the amount of adsorbed NO3-_N on the surface of iron [9], thus resulting in slight changes of NH4+-N. 


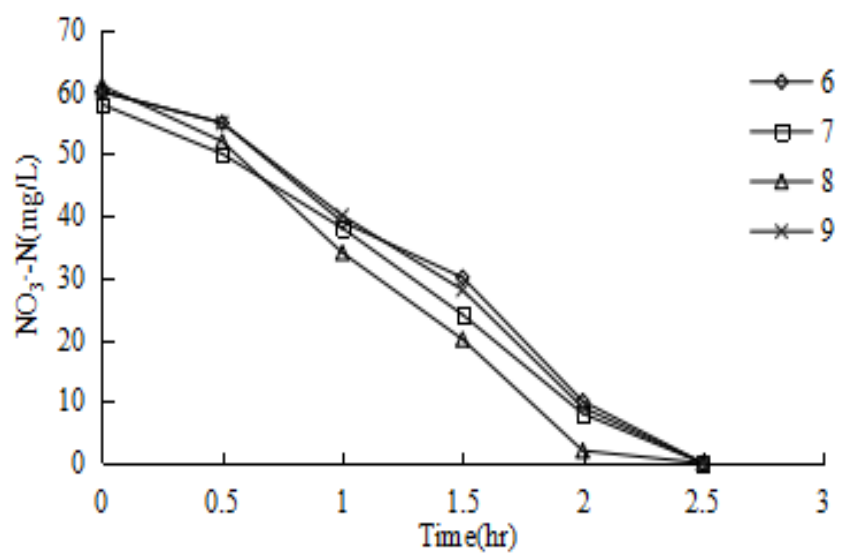

Figure 3. $\mathrm{NO}_{3}{ }^{-}-\mathrm{N}$ removal at different $\mathrm{pH}$ (NZVI $10 \mathrm{ml}$, activated sludge $100 \mathrm{ml}, \mathrm{NO}_{3}{ }^{-}-\mathrm{N}$ loading $65 \mathrm{mg} / \mathrm{L}, \mathrm{H}_{2}$ pressure $0.05 \mathrm{MPa}$, temperature $\left.30^{\circ} \mathrm{C}\right)$

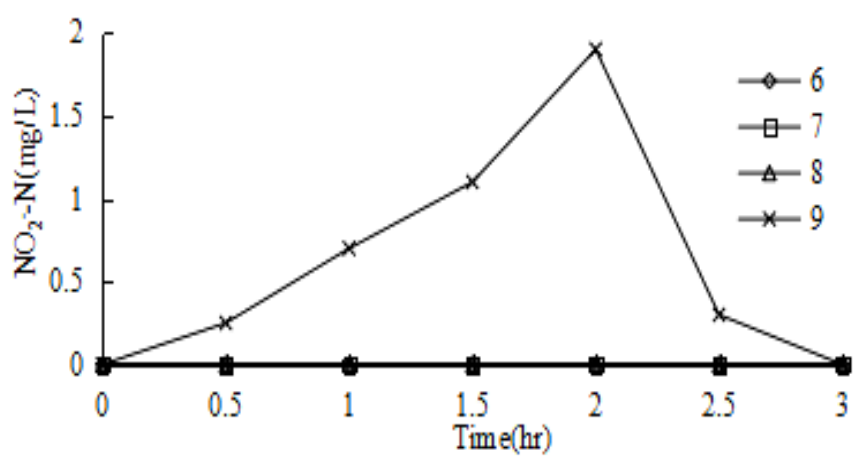

Figure 4. $\mathrm{NO}_{2}{ }^{-}-\mathrm{N}$ accumulation at different pH (NZVI $10 \mathrm{ml}$, activated sludge $100 \mathrm{ml}, \mathrm{NO}_{3}{ }^{-}-\mathrm{N}$ loading $65 \mathrm{mg} / \mathrm{L}, \mathrm{H}_{2}$ pressure 0.05 $\mathrm{MPa}$, temperature $30^{\circ} \mathrm{C}$ )

\section{Effect of nitrate loading}

Fig. 5 revealed the NO3-_N degradation performance with different initial NO3-_N concentration. It's obvious that an average NO3-_N degradation rate of $20-30 \mathrm{mg}$ NO3-_N/L/h was obtained at initial concentration varying from 25 to $150 \mathrm{mg} / \mathrm{L}$. A higher NO3-_N loading required more time for complete reduction ( $1 \mathrm{~h}$ for $25 \mathrm{mg} / \mathrm{L}$ to $6 \mathrm{~h}$ for $150 \mathrm{mg} / \mathrm{L}$ ). The highest removal rate $(30 \mathrm{mg}$ NO3_N/L/h) was observed at $105 \mathrm{mg} / \mathrm{L}$. In addition, effluent NH4+-N fluctuated slightly and was always below $1.0 \mathrm{mg}$ $/ \mathrm{L}$.

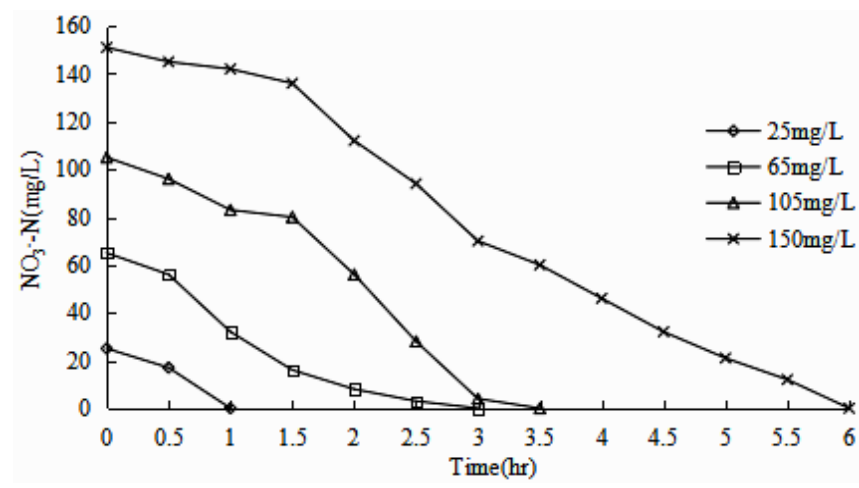

Figure 5. $\mathrm{NO}_{3}{ }^{-}-\mathrm{N}$ degradation at different $\mathrm{NO}_{3}{ }^{-}-\mathrm{N}$ loading (NZVI $10 \mathrm{ml}$, activated sludge $100 \mathrm{ml}, \mathrm{pH} 7.0, \mathrm{H}_{2}$ pressure $0.05 \mathrm{MPa}$, temperature $35^{\circ} \mathrm{C}$
The results were consistent with those by Yang et al [9]. confirming the effective reduction power of NZVI in treating highly concentrated mg NO3-_N. High level of NO3-_N could result in NO2-_N accumulation of during the NO3-_N reduction [18]. However, no accumulated NO2-_N was seen over operation. This might be explained by the different reaction route as (1) and (2), for the intermediate NO2--N could be timeously converted into N2:

Effect of atmospheres

Fig. 6 showed the effect of different filling atmosphere on NO3-_N reduction. It was apparent that NO3-_N degradation rate of coupling system with sufficient $\mathrm{H} 2$ was $22 \mathrm{mg} \mathrm{NO} 3$-_N/L/h, which was much higher than that with N2 (11 mg NO3-_N/L/h). During the operation, there was no NO2-_N accumulated and the $\mathrm{NH} 4+-\mathrm{N}$ was below $1.0 \mathrm{mg} / \mathrm{L}$.

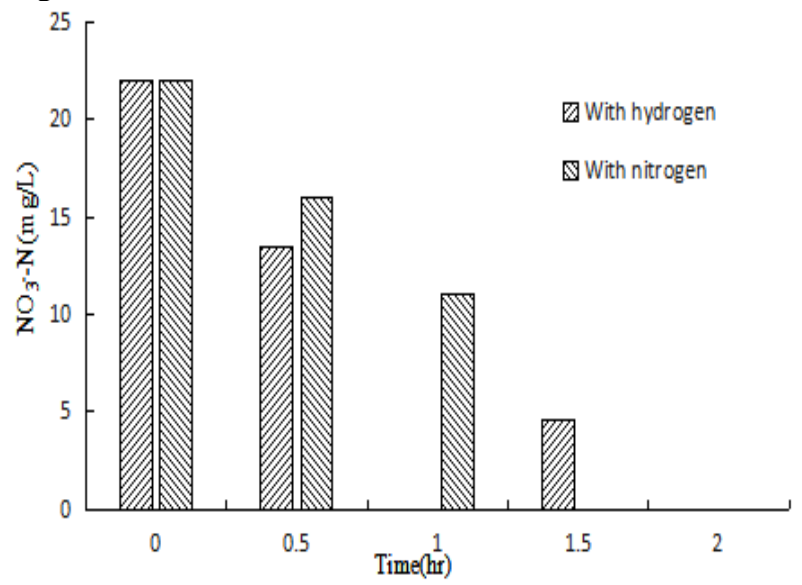

Figure 6. $\mathrm{NO}_{3}^{-}-\mathrm{N}$ degradation performance at $\mathrm{H}_{2} / \mathrm{N}_{2}$ atmosphere (NZVI $10 \mathrm{ml}$, activated sludge $100 \mathrm{ml}, \mathrm{pH} \mathrm{7.0,} \mathrm{NO}_{3}^{-}-\mathrm{N}$ loading $22 \mathrm{mg} / \mathrm{L}$, temperature $30^{\circ} \mathrm{C}$ )

Previous studies by Mousavi et al.[19] showed that biological denitrification failed to operate without injecting $\mathrm{H} 2$ as electron donor in an activated sludge reactor. Therefore, there might be two reasons: chemical denitrification process of NZVI in coupling system reduced NO3-_N, which remained unaffected by the presence of $\mathrm{H} 2$ [20]; $\mathrm{H} 2$ produced by micro-electrolysis of NZVI [21] served as electron donor for denitrification, thus aiding the denitrification process.

\section{CONCLUSIONS}

The aim of this work was to investigate the effects of important parameters including $\mathrm{Fe} / \mathrm{N}$, pH, nitrate loading, and atmosphere on NO3-_ $\mathrm{N}$ in a combination of chemical denitrification by NZVI with autohydrogenotrophic denitrification system.

NZVI could greatly strengthen the reaction rate of couple system compared with individual biological denitrification. The optimum Fe/ $\mathrm{N}$ was 2.8 for present study. Dentrification efficiency changed slightly when $\mathrm{pH}$ varied from 6.0 to 9.0 , but nitrite would accumulate when $\mathrm{pH}$ was 9.0. This coupling system could cope with nitrate ranging from 25 to $155 \mathrm{mg}$. The highest denitrification rate reached $30 \mathrm{mg} \mathrm{NO} 3$ __N$_{\mathrm{N}} / \mathrm{h}$ at initial NO3-_N loading of $105 \mathrm{mg} / \mathrm{L}$. In addition, the supply of $\mathrm{H} 2$ could aid denitrification of couple system for both chemical and biological mechanisms. 
Given the complete NO3-_N removal at various conditions, that coupling system had strong stability and adaptability for further practical application.

\section{ACKNOWLEDGMENT}

This work was financially supported by the National Natural Science Foundation of China (NSFC) (No. 51008239 and 51378400) and the Natural Science Foundation of Hubei Province, China (No. 2013CFB289).

\section{REFERENCES}

[1] Jiang, W, Qu, J. H, Lei, P. J, Liu, S. X. \& Meng, G. H. Nitrate nitrogen removal from ground water by autotrophic denitrification in a packed bed reactor. China Environment. (2001) Sci.21, 133136.

[2] S. Ghafari, M. Hasan, M.K. Aroua, Bio-electrochemical removal of nitrate from water and wastewater-Areview, Bioresour. Technol. 99 (2008) 3965-3974

[3] EPA. Discharge standards of pollutants for municipal wastewater treatment plant (GB 18918-2002). Standard Press of China.

[4] M.H. Zhou, W. Wang, M.L. Chi, Enhancement on the simultaneous removal of nitrate and organic pollutants from groundwater by a three-dimensional bio-electrochemical reactor, Bioresour. Technol. 100 (2009) 4662-4668.

[5] M. Li, C. Feng, Z. Zhang, X. Lei, R. Chen, Y. Yang, N. Sugiura, Simultaneous reduction of nitrate and oxidation of by-products using electrochemical method, J. Hazard. Mater. 171 (2009) 724730.

[6] Ghafari, S., Hasan, M. \& Aroua, M. K . Bio-electrochemical removal of nitrate from water and wastewater: A review.Bioresour. Technol. 99 (2008), 3965-3974.

[7] Xia, S. Q., Zhong, F. H., Zhang, Y. H., Li, H. \& Yang, X. Bioreduction of nitrate from groundwater using a hydrogenbased membrane biofilm reactor. J. Environ. Sci. 22 (2010), 257-262.

[8] Mousavi, S, Ibrahim, S, Aroua, M. K. \& Ghafari, S. Development of nitrate elimination by autohydrogenotrophic bacteria in bio-electrochemical reactors - A review. Biochem.Eng. J. 67 (2012), 251-264.
[9] Yang, G.C; Lee, H.L. Chemical reduction of nitrate by nanosized iron: Kinetics and Pathways. Water Res. 39 (2005), 884-894.

[10] Hwang, Y.H.; Kim, D.G.; Shin, H.S. Mechanism study of nitrate reduction by nano zero-valent iron. J. Hazard. Mater. 185 (2011), 1513-1521.

[11] Shin K. H. \& Cha D. K. Microbial reduction of nitrate in the presence of nanoscale zero-valent iron. Chemosphere. 72 (2008), 257-262.

[12] APHA (2005) Standard methods for the examination of water and wastewater. American Public Health Association (APHA): Washington, DC, USA.

[13] Noubactep, C; Caré, S. On nanoscale metallic iron for groundwater remediation. J. Hazard. Mater. 182 (2010), 923-927.

[14] Ruangchainikom, C.; Liao, C.H.; Anotai, J.; Lee, M.T. Effects of water characteristics on nitrate reduction by the $\mathrm{Fe} / \mathrm{CO} 2$ process. Chemosphere .63 (2006), 335-343.

[15] Lee, K. C. \& Rittmann, B. E. Effects of $\mathrm{pH}$ and precipitation on autohydrogenotrophic denitri fi cation using the hollow fi ber membrane-biofilm reactor. Water Res. 37 (2003), 1551-1556.

[16] Rezania, B., Cicek, N. \& Oleszkiewicz, J. A. Kinetics of hydrogen-dependent denitri fi cation under varying $\mathrm{pH}$ and temperature conditions. Biotechnol. Bioeng. 92 (2005a), 900-906.

[17] Rezania, B., Oleszkiewicz, J. A., Cicek, N. \& Mo, H. Hydrogendependent denitrification in an alternating anoxicaerobic SBR membrane bio-reactor. Water Sci. Technol. 51 (2005b),403-409.

[18] H.I. Park, D.K. Kim, Y. Choi, D. Pak, Nitrate reduction using an electrode as direct electron donor in a biofilm-electrode reactor, Process Biochem. 40 (2005), 3383-3388.

[19] Mousavi, Seyyedalireza; Ibrahim, ShalizaAroua; 2014, Mohamed Kheireddine. Effects of operational parameters on the treatment of nitrate-rich wastewater by autohydrogenotrophic denitrifying bacteria.Water and Environment Journal. Vol.4 (2014), 556-566.

[20] Huang, C.P.; Wang, H.W.; Chiu, P.C. Nitrate reduction by metallic iron. Water Res. 32 ( 1998), 2257-2264.

[21] Li Xiao, Zhenhai,Suqin Cia, Junhong Chen, Zhen He. Carbon/iron-based nanorod catalysts for hydrogen production in microbial electrolysis cells.Nano Energy.Vol 3(2012), 751-756. 